\title{
"Theoretical and methodological basis for technology transfer from universities to the business environment"
}

\begin{tabular}{|c|c|}
\hline AUTHORS & $\begin{array}{l}\text { Nataliya I. Chukhray iD https://orcid.org/0000-0001-8591-2487 } \\
\text { Oleksandra Mrykhina iD https://orcid.org/0000-0002-0567-2995 }\end{array}$ \\
\hline ARTICLE INFO & $\begin{array}{l}\text { Nataliya I. Chukhray and Oleksandra Mrykhina (2018). Theoretical and } \\
\text { methodological basis for technology transfer from universities to the business } \\
\text { environment. Problems and Perspectives in Management, 16(1), 399-416. } \\
\text { doi:10.21511/ppm.16(1).2018.38 }\end{array}$ \\
\hline DOI & http://dx.doi.org/10.21511/ppm.16(1).2018.38 \\
\hline RELEASED ON & Monday, 02 April 2018 \\
\hline RECEIVED ON & Saturday, 09 December 2017 \\
\hline ACCEPTED ON & Tuesday, 30 January 2018 \\
\hline LICENSE & $\begin{array}{l}(\boldsymbol{c c}) \text { EY-NC } \\
\text { This work is licensed under a Creative Commons Attribution-NonCommercial } 4.0 \\
\text { International License }\end{array}$ \\
\hline JOURNAL & "Problems and Perspectives in Management" \\
\hline ISSN PRINT & $1727-7051$ \\
\hline ISSN ONLINE & $1810-5467$ \\
\hline PUBLISHER & LLC "Consulting Publishing Company "Business Perspectives" \\
\hline FOUNDER & LLC "Consulting Publishing Company "Business Perspectives" \\
\hline & $\begin{array}{l}\text { ニ-: } \\
\text { =-:- }\end{array}$ \\
\hline NUMBER OF REFERENCES & NUMBER OF FIGURES \\
\hline 47 & 0 \\
\hline
\end{tabular}

(C) The author(s) 2023. This publication is an open access article. 


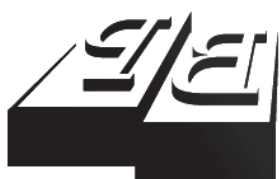

BUSINESS PERSPECTIVES

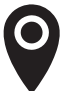

LLC "CPC "Business Perspectives" Hryhorii Skovoroda lane, 10, Sumy, 40022, Ukraine

www.businessperspectives.org

Received on: $9^{\text {th }}$ of December, 2017 Accepted on: $30^{\text {th }}$ of January, 2018

(C) Nataliya I. Chukhray,

Oleksandra B. Mrykhina, 2018

Nataliya I. Chukhray, D.Sc. (Economy), Professor, Vice Rector for Scientific Research, Lviv Polytechnic National University, Ukraine.

Oleksandra B. Mrykhina, Ph.D., Associate Professor, Lviv Polytechnic National University, Ukraine.

\begin{abstract}
The modern concept of open innovation highlights the role of technology transfer from universities to the business environment. An increase in technology transfer efficiency is one of the tasks assigned to Ukrainian universities by the state. The nature of technology transfers in the world and the role of universities in this process call for revising traditional approaches to its production in Ukraine. This stipulated the substantiation of theoretical and methodological principles of technology transfer from universities to the business environment, which should serve as a fundamental platform for further economic, technological and other actions in the innovation development of Ukraine. For this purpose, the modern theoretical and applied components of technology transfer from universities to the business environment are researched; the theoretical and methodological principles of technology transfer are determined and the conceptual approach to understanding technology transfer from universities to the business environment is proved. To achieve the tasks at hand, the background and trends in technology transfer from universities to the business environment have been researched; the role of universities in modern technology transfers is analyzed; the peculiarities and potential of the scientific area of Ukraine are considered; the influence of university technology transfer centers on the universities' academic entrepreneurship has been studied; the nature of knowledge transformation during the technology transfer is substantiated; the influence of technology transfer on the university subsystems is considered; the effects of technology transfer are investigated; models of interaction in the system "University - Governmental Authority - Business" are studied; and modern approaches to the technology transfer from universities to the business environment are researched. Given the research conducted, theoretical and methodological principles for technology transfer were formed, which conceptualize the technology transfer from universities to the business environment.
\end{abstract}

\section{Keywords}

\section{JEL Classification} entrepreneurship, technological development

$\mathrm{M} 10, \mathrm{O} 33$

\title{
INTRODUCTION
}

The increased use of open innovation in developed countries brings to the fore the problem of technology transfer, namely the key role is assigned to the technology transfer from universities to the business environment. In recent years, technology transfer from the university environment has become an increasingly important source of regional economic development and university profits, significantly exceeding other types of technology transfer. The universities' influence is manifested in the implementation of innovative $\mathrm{R} \& \mathrm{D}$ and their results, as well as in the creation of an innovative ecosystem, platforms of interaction between investors and developers. 
The world-wide changes determined by technology transfer (the 4th Industrial Revolution, academic entrepreneurship development, etc.) give grounds for talking about the transition of society to the newest understanding of technology transfer, where universities are increasingly becoming key players, both from the perspective of technology development opportunities and entrepreneurial development. This applies not only to foreign countries, in which universities historically were the dominant centers of research concentration, but also to post-socialist countries, where, unlike other economies, universities were seen primarily as educational institutions.

The modern innovation and technological progress of the Ukrainian economy is based on the integrated interaction of education, science, business organizations and government. Knowledge is becoming a productive factor, as evidenced by the current legislation (Laws of Ukraine "On Higher Education" as of July 1, 2014, No. 1556-VII; "On State Regulation of Activity in the Sphere of Transfer of Technologies" as of September 14, 2006, No. 143-V; "On Scientific Parks" as of June 25, 2009, No. 1563-VI; "On Scientific and Scientific and Technical Activity" dated November 26, 2015, No. 848-VIII and others) and a number of legal documents. Increasing the technology transfer efficiency has become one of the missions assigned to Ukrainian universities by the state.

Official statistics indicate that during 2016, scientific and scientific-technical work in Ukraine was carried out by 972 organizations, $15.7 \%$ of which belonged to the higher education sector (Державна служба статистики України [Derzhavna sluzhba statystyky Ukrainy]). This indicates the significant scientific and technological potential of the domestic higher education sector, and hence the ability to generate technologies that can be transferred to business. At the same time, the number of transferred new technologies (technical achievements) in Ukraine (in aggregate, for all economic entities) was 28 units in 2014 and 98 units in 2015. The number of transferred technologies outside Ukraine was 8 units in 2014 and 20 units in 2015. The purchase of new technologies significantly exceeded their transfer: in Ukraine, 426 units were purchased in 2014 and 1,131 units in 2015, 117 units were purchased abroad in 2014 and 66 units in 2015 (Державна служба статистики України [Derzhavna sluzhba statystyky Ukrainy]). There is an imbalance: in the context of sufficiently high potential for the production of scientific and technical products, domestic universities do not release it in the proper amount and, accordingly, do not receive an appropriate commercial result.

Modern features and trends of technology transfer in the world and the role of universities in this process determine revising the traditional approaches to its implementation in Ukraine. This necessitated the development of theoretical and methodological principles for the technology transfer, which would become the basis for the modern technology transfer, actualize the current role of universities in the technological development of Ukraine. The theoretical and methodological principles for technology transfer from universities to the business environment should serve as a fundamental platform for further economic, technological and other actions in the field of innovative development of Ukraine.

\section{RECENT RESEARCH AND PUBLICATIONS ANALYSIS}

Technology transfer is a complex, multifactorial process, the individual aspects of which were studied by a number of scientists. In particular, Butenko and Tkachuk (2015) and Dovbenko (2013) highlight the general provisions for the technology transfer, commercialization and innovation development. Salikhova (2003) offers her own vision of the methodological support for the study of in- ternational technology transfer in Ukraine. Kniaz and Heorhiadi (2011) focus on technology transfer in the context of the transfer potential research.

While considering the technology transfer, scientists are mostly based on technology originating from enterprises. In particular, Izhevskyi (2006) developed theoretical and methodological principles for justifying the choice and evaluation of the effective technology transfer to encourage technological development of production enter- 
prises. Liashenko (2009) substantiated the methodological principles for modeling the technology transfer commercialization and developed economic-mathematical models to form the national system of technology transfer. Some scientists pay attention to the technology transfer in the sectoral section. In particular, Kosenko (2016) developed the theoretical and methodological principles for the organizational and economic mechanism of commercialization of intellectual and innovative technologies and practical recommendations for their implementation at the domestic machine-building enterprises. For the enterprises of mechanical engineering, Kamianska (2008) systematized theoretical principles and developed scientific-methodical and scientific-practical recommendations on technology transfer management. Androsova (2006) paid attention to the development of theoretical and methodological approaches and practical recommendations for improving efficiency of research and development based on technology transfer in the production of engines in the aircraft industry and technology parks.

Illiashenko (2011), Pererva and Hladenko (2010), Shcherbata (2016), Yastremska (2010) and others analyze the issues of organizational and methodological support for the technology transfer and the role of universities in this process. Tsybuliov et al. (2005), Butnik-Siverskyi (2006) consider technology transfer from universities to the business environment in the context of evaluating intellectual property objects.

An analysis of the Ukrainian scholars' works in technology transfer showed that most of them are investigating the transfer of technologies from highly specialized positions. In Ukraine, the problem of technology transfer is not considered in the theoretical and methodological context, since the attention is focused locally on the second order issues- practical implementation of technologies. At the same time, the lack of fundamental principles during the organization of any process violates its effectiveness in the future.

Bercovitz and Feldman (2006) are among those considering technology transfer and academic entrepreneurship. They describe the impact of economic, social and political factors on the abil- ity of universities to generate new knowledge and use them in a cost-effective way. The authors' approach contributes to the general understanding of the relations of educational and scientific institutions with industry, and the role of universities in knowledge-based innovation systems.

Gibson and Smilor (1991) studied the conditions and peculiarities of technology transfer and highlighted four main variables - communication interactivity, cultural and geographical distance, technological multidimensionality and personal motivation. These variables are central elements of technology transfer within and between organizations.

Etzkowitz (1983), Carayannis and Campbell (2009) paid a lot of attention to the substantiation of the role of universities in the technology transfer processes in the "University - Governmental Authority - Business" system. They have proved a spiral connection between the identified system components, which determines the nature of technological development of countries. Etzkowitz (1983) published a number of articles, which substantiated the importance of focusing on transfer of those technologies that originate from universities.

Mansfield (1975) was one of the first who noted that the technology transfer is among the leading processes determining the country's economic efficiency. Friedman and Silberman (2003) substantiated the modern determinants of technology transfer, in particular, those developed at universities. The authors pointed to the important role of university technology transfer offices.

Chen et al. (2010), based on studying the characteristics of research as the basis of technology transfer, allow us to determine the development map, trends and regularities in this area.

Chesbrough and Vanhaverbeke (2006) justified the concept of open innovation. The concept makes the processes of technology transfer actual and at the same time, it occurs thanks to this actualization. In addition, the authors have substantiated that in the last decades, in technologically developed countries, universities played the main role in the technology transfer. 
The materials of the Association of Technology University Managers (2017), which since 1991 conducted research on the transfer of technology from the university environment to business structures, point to the explosive growth of the universities' role in recent years. The scientistsmembers of the Federal Laboratory Consortium for Technology Transfer (Bickmore \& Law, 2013) speak for the increase in the efficiency of technology transfer developed in laboratories created by university-based companies.

Mayer and Blaas (2002) offered their research results, which became the basis for active support for the technology transfer in Austria, with great attention to the process of technological development given to universities. The scientists note that, over the last decades, small and mediumsized enterprises have begun using technology transfer as a strategic tool to address the challenges posed by business globalization. Due to their small size and limited resources, they cannot carry out internal R\&D and create their own technological products. At the same time, the new technologies flow is needed to compete. To this end, small and medium-sized enterprises refer to universities, accumulating university capacities to generate technology and commercialization opportunities.

The reports of scientists presented at the conferences of the World Intellectual Property Organization during recent years point to the need to reformat the world public perception of the technology transfer phenomenon and the role of universities in this process.

Foreign scientific research is very important with regard to applying certain technology transfer aspects, which at the same time require a thorough elaboration to be adapted in Ukraine.

While summarizing the scientists' experience, here becomes apparent the actualization of universities' role in the world technological progress, which is mediated by technology transfer. In Ukraine, such an approach is only gaining momentum, as at this time, the main reason for this has not been developed - the theoretical and methodological principles of technology transfer, in particular focusing on universities.
The purpose of the paper is to substantiate the theoretical and methodological principles of technology transfer from universities to the business environment. To do this, the following tasks were set and solved: 1) to study the modern theoretical and applied components of technology transfer from universities to the business environment; 2) to determine the theoretical and methodological principles of technology transfer, as well as to substantiate the conceptual approach to the understanding of the technology transfer from universities to the business environment.

\section{KEY RESEARCH RESULTS}

Theoretical and methodological principles of technology transfer from universities to the business environment are a set of theoretical and methodological provisions on construction, forms and methods for implementing this type of technology transfer. A certain set of methods and models that applied when transferring technology from universities to the business environment makes its methodology.

The development of theoretical and methodological principles of technology transfer from universities to the business environment is an important part of the economic science development: any technology transfer activity has not only substantive, but also methodological content related to the evolutionary redefinition of existing approaches to the technology transfer, preconditions and approaches to its interpretation, etc.

The modern nature of the technology transfer from universities to the business environment is determined by the knowledge transformation chain, which develops theoretical and methodological principles and conceptual model of technology transfer. In this case, universities play the determining role.

The theoretical and methodological principles of technology transfer from universities to the business environment are determined based on studying its main components in the field of science and practice. Let us consider them in more detail. 
1. Universities in modern technology transfer processes. Etzkowitz (1983) introduced the term of "entrepreneurial university" to describe the new nature of the changes reflecting the universities' role in the academic research transfer. Although large enterprises are able to carry out $\mathrm{R} \& \mathrm{D}$ on their own, as of today, the scientific research transfer on outsourcing by external actors of technology generation with a view to their transfer has shown higher efficiency. The tendency exists that such enterprises establish their offices on the basis of universities that are engaged in innovation activities (or organize branches of university departments), thus reducing the time between scientific discovery and its implementation. Often, the combination of universities and various research subjects, networks of enterprises and other business entities based on the infrastructure of entrepreneurship and technology transfer causes the emergence of "academic clusters". The study indicates that successful technology transfer from universities depends on existing innovation infrastructure and relevant lawyers, venture capitalists, consultants, entrepreneurs and researchers working in the field.

There are more than 200 technological universities in Ukraine, which gives reason to talk about the significant potential for technology transfer from universities to the business environment.

The developed countries economy is characterized by a tendency to demand R\&D in universities, which causes, for the latter, increased competition. Ukraine has also such experience, but it is only gaining momentum (Department Branch of Semiconductor at Lviv Polytechnic National University on the basis of "Electron" of R\&D company "NAUKA", laboratory of "EPAM" at Lviv Polytechnic National University, etc.). However, this process does not occur systematically and therefore the commercialization of technologies at universities is not extensive.

2. Peculiarities and potential of the scientific area of Ukraine. In Ukraine, the growth rate of GDP due to the new technologies introduction is less than $1 \%$, while in developed countries, it is $60-90 \%$ (Grosul, 2010, p. 77). At the same time, according to majority of scientists, Ukraine is in the top ten world leaders. It is advisable to analyze this dissonance based on a number of international rating assessments.

In particular, according to the Global Innovation Index, in 2016, Ukraine ranked 56th among 128 countries, against 64th in 2015 among 141 countries. Universities are directly related to a number of indicators within the Global Innovation Index (in particular, such as the number of graduates in technical specialties, the number of researchers, the place of universities in international rankings, the cooperation of business and universities in the area of $\mathrm{R} \& \mathrm{D}$, the number of applications submitted and patents received, Hirsch citation index, etc.). Despite the fact that according to some quantitative indicators (the share of education expenditures in the country's GDP, the number of graduates in technical specialties, etc.) in 2015, Ukraine ranked slightly better than, for example, the United Kingdom, the qualitative indicators (place of universities in international rankings, the quality of scientific publications, etc.) remain significantly lower. In particular, the share of R\&D expenditure in Ukraine's GDP is twice lower than in the UK.

According to the Global Competitiveness Index highlighted by the World Economic Forum in the Global Competitiveness Report (Schwab, 2017), Ukraine is relatively diametrically positioned. Being on the 85th place in 2016-2017 among 138 countries, the indicators reflecting the innovative progress of Ukraine indicate an average level of development. In particular, Ukraine's innovation development is evidenced by indicators in the sub-index C, key task of which is to reflect the various aspects of innovation and technology intellectualization, such as 49 - innovation capacity, 50 - quality of research institutes, 29 - presence of scientists and engineers, 49 - PCT patents (applications for the PCT procedure for 1 million people), etc. Thus, factors indicating the country's innovative potential show that there are prospects in the field of domestic technological development.

The cross-comparison of indices of scientific and educational sphere, innovations, and technologies within the Global Competitiveness Index points to their divergence and, consequently, different effectiveness and influence on this index: according 
to the level of higher education coverage in 20162017, Ukraine ranked 11th - sufficiently high position, and according to state-of-the-art technologies - 98th place, low position. To some extent, this indicates the non-continuous development of business structures and universities.

According to the country innovativeness ranking by Bloomberg (Bloomberg Finance L. P.), in 2015, Ukraine ranked 33rd, entering the fifty most innovative countries of the world (in 2014 - 49th position). The results of the analysis of technology transfer and innovative activity in Ukraine from the international ratings' positions have shown that Ukraine has the prospects for raising the innovation level, first of all, by promoting the innovation activity of universities and research institutions on the basis of cooperation with business structures. However, at present, universities with the available scientific and technological potential do not adequately meet the challenges of the market environment.

A great obstacle to the innovative development of Ukraine is the insignificant demand for scientific and technical developments, both from the state and from the private business. The size of budget expenditures for science in Ukraine is $0.3-0.5 \%$ of GDP annually, while in the EU countries, this figure is more than $3 \%$ of GDP (Інноваційна Україна - 2020. Доповідь [Innovatsiina Ukraina - 2020. Dopovid], 2015). The value of R\&D expenditures as a share of GDP in the EU and Ukraine (2016) is shown in Figure 1.
Here should be noted the growing number of $R \& D$ expenditures in Ukraine (from UAH 8,107.1 mln in 2010 to UAH 11,530.7 mln in 2016 (Державна служба статистики України [Derzhavna sluzhba statystyky Ukrainy], 2016), while the number of researchers in Ukraine decreased to about 70,000 people in 2014, representing $22 \%$ of the number of researchers in 1990. At the same time, in the EU countries, the number of researchers increased: in 2015, it was 1,730.0 thousand (Державна служба статистики України [Derzhavna sluzhba statystyky Ukrainy], 2016) (equivalent to full employment), which is $41.0 \%$ more than the same indicator in 2005 , the total number of $R \& D$ performers in 2015 was about $1.1 \%$ of the labor force of the EU countries (the highest share is typical for Denmark, Finland and Luxembourg, and the lowest is for Romania and Cyprus).

In Ukraine, in 2014, only 18 educational institutions have developed advanced technologies, 39 have used advanced technologies, 23 have used intellectual property rights (IPOs), and 4 have applied innovation proposals (Державна служба статистики України [Derzhavna sluzhba statystyky Ukrainy], 2016). Such statistics confirms that in the domestic education, a small number of institutions is involved in the creation, use of advanced technologies and the use of IPOs. In particular, according to statistics (Державна служба статистики України [Derzhavna sluzhba statystyky Ukrainy], 2016), out of 106 enterprises that have created advanced technologies, only one in six is an educational institution; of the 162

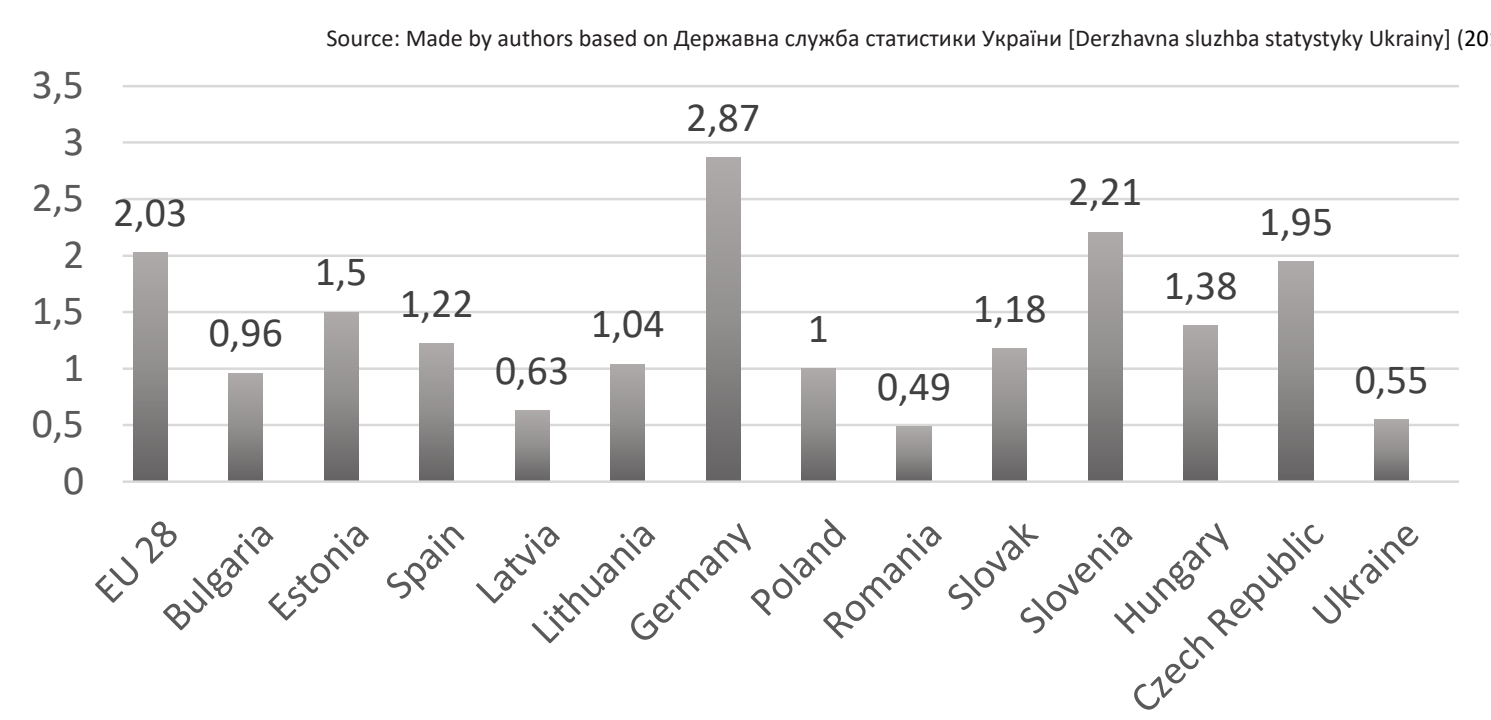

Figure 1. Specific weight of R\&D expenditures as part of GDP in EU countries and Ukraine, 2016, \% 
protection documents for inventions, 78 protection documents were received by educational institutions. As for industrial standards, only 189 protection documents were received by educational institutions. This indicates the interrupted relationship between universities and business. Educational institutions occupy an unsatisfactory position by the number of advanced technologies used. In particular, out of 17.4 thousand used technologies in 2014 in Ukraine, only 579 (3.3\%) were in the university environment (Державна служба статистики України [Derzhavna sluzhba statystyky Ukrainy], 2016). Only 49 (or 4\%) of the total inventions (1,218 units) used in technology for the entire time of implementation were in education (Державна служба статистики України [Derzhavna sluzhba statystyky Ukrainy], 2016).

It should be noted that in the Ukrainian innovation infrastructure, there is virtually no venture funds, no bases are formed, funding for the technology development and transfer based on publicprivate partnership is not established. Leveling the achievements of the domestic science is a popular phenomenon, because enterprises buy foreign (audited) technologies that are outdated at the time of purchase: by not applying innovations, they produce goods absorbed by the domestic market (based on competitive prices and a slightly updated external form; with the following product factors such as environmental friendliness, ergonomics, resource conservation, etc. are not considered).

The scientific area in Ukraine has large potential, but its use is characterized by low productivity, the reasons for which are low investment in the economy, underdevelopment of scientific management, inappropriate resource use, etc. An important issue is the rationale for promising directions of financial and economic support for education and science, which would correspond to long-term forecasts of technological development of Ukraine.

3. University technology transfer centers as a key factor of academic entrepreneurship. In order to intensify the technologies commercialization at universities, the technology transfer centers (TTC) are created. For example, the Massachusetts Institute of Technology and the Stanford University have established technology licensing offices; the Cornell University, the Federal Polytechnic in Zurich, the majority of universities in the Eastern European countries (in particular, Poland), namely Lodz Polytechnic, Jagiellonian University, Krakow Polytechnic, Wroclaw Polytechnic, etc., developed Centers for Technology Licensing. To stimulate the technology transfer, the University of Oxford, in 1988, created a university company - ISIS Innovation Ltd. (from June 2016 - Oxford University Innovation), which operates on a regular basis and is responsible for the implementation of all technology transfer stages.

With the TTC in the structure, universities can be not only actors of technology generation, but also centers providing services for the commercialization of technologies developed by other business entities. TTC or other similar units allow both their developers and other business entities to reduce the path of "R\&D $\rightarrow$ Production $\rightarrow$ Market (Commercialization)". The functions of TTC include the preparation of technologies for transfer (transferability assessment, technology market research, counteragent and investor search, studying the type of transfer, etc.), as well as technology transfer. TTC are the main drivers of academic entrepreneurship.

The experience of the developed countries (the Silicon Valley in the United States, the Irish and Israeli ecosystem of innovation, etc.) showed that without a university unit such as TTC, it is difficult to achieve efficient technology transfer and business success. In the world, almost all leading research universities have their own TTCs (offices, subdivisions, etc.). As a rule, there is a time lag of three to seven years from the date of signing the license agreement to the time the technology (product) starts to generate profits. The technology is gradually diffused, resulting in a corresponding income increase. With this in mind, TTCs operating on the market over a long period of time are more efficient in their business as compared to newly created entities.

In Ukraine, according to the Concept of National Innovation System Development, 2009, TTC has been approved as one of the innovation infrastructure elements. At the same time, although scientists, practitioners and government officials unan- 
imously recognize the need for the TTC creation at the universities (in particular, the Foresight of the Ukrainian Economy, the Strategy for the hightech industries development until 2025, etc.), an effective mechanism for their establishment and functioning has not yet been developed. University TTCs are in their infancy and this has a negative impact on academic entrepreneurship.

In our opinion, one of the ways to intensify the TTC creation at universities should be developing their own concept of technology transfer by each university. This will enable, on the one hand, to take into account the specifics of the university, and on the other hand, to identify the technology transfer nature, inherent in this university and the region. The concepts will demonstrate the advantages and "bottlenecks" of technology transfer undertaken by the university, as well as indicate the necessary form and features of a specific TTC. To do this, the preconditions should be laid down within the framework of academic entrepreneurship on the basis of modern theoretical and methodological principles of technology transfer from universities to the business environment.

4. Transformation of knowledge during technology transfer. Understanding the nature of technology in the modern context of technology transfer is an important basis for any manufacturing process. Technology is a multifaceted social phenomenon. By its content, technology is an effect on the knowledge resulted from the implementation of other technologies, which also arose as a result of knowledge development. Speaking about the concept of technology in the context of its further transfer, in our opinion, it is important to consider it as a commodity.

Technology is a product of labor or it is a good capable of meeting certain human needs and intended for exchange (purchase, sale). This is confirmed by the provision of the Law of Ukraine "On Scientific and Scientific and Technical Activity", which states that scientific (scientific and technical) products are scientific and/or scientific and technical (applied) results intended for implementation (Law of Ukraine "On Scientific and Scientific and Technical Activity", 2017, Section I, Article 1, p. 14). Thus, according to the ideological essence of the Law, the scientific and technological product (technology) obtained at the university and resulted from R\&D must be suitable for implementation and generate a commercial (social, ecological, etc.) effect. That is, technology is a product that is implemented in accordance with the marketing laws.

From the classical marketing standpoint, the product is characterized by three levels of its expression: core product, actual product - in a tangible form, and augmented product - in intangible form. Technology as a product also combines all three of the aforementioned levels, in particular: level 1 - know-how, level 2 - object-based producttechnology as a set of documentation for product creation, and level 3 - user maintenance as the scientific and technical support.

Knowledge as the intangible component of technology, transferred along with the object-based product-technology from the second level to the third, initiates new knowledge associated with the emergence of new entities in this process. Thus, the intangible component of technology enhances its material component. Such an approach to technology as a commodity is an important basis for the technology transfer. For example, in developing strategies for technology transfer, it will allow to consider the phenomena that were previously thought to be mediated to the technology transfer: synergy, convergence, spillover effect, multiplicity and others. According to this approach, more attention should be paid to interdisciplinary communication and the role of knowledge that enhances the tangible component of technology in their transfer. Schematically, the moment of transforming knowledge into technology during transfer and generation based on this new knowledge is shown in Figure 2.

When the knowledge $(\mathrm{K})$ is used to create the technology $(\mathrm{T})$, then the implementation of $(\mathrm{T})$ will lead to a new development stage (K'), which will be different from $(\mathrm{K})$, embedded in the beginning. Knowledge embodied in technology and transferred from a developer to a buyer who, having implemented them in production (materializing), adds to them his own value while introducing the technology into practical activities, receives new knowledge $\left(\mathrm{K}^{\prime}\right)$, the added value of which con- 


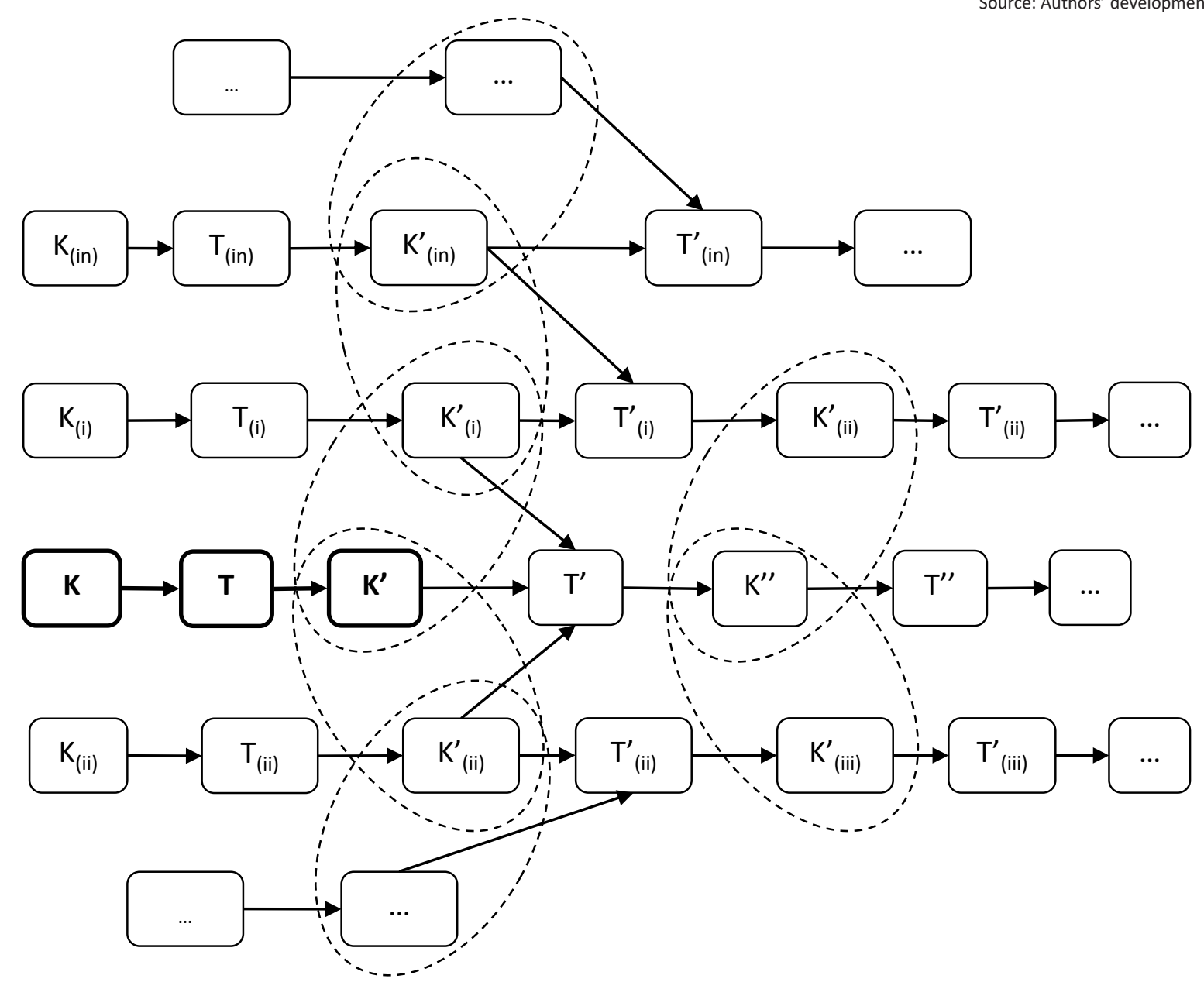

Note: The dotted line indicates areas of various effects resulting from the creation, dissemination and aggregation of technologybased knowledge.

Figure 2. Schematic representation of knowledge transformation chains during the technology transfer

sists in practical implementation $(\mathrm{K})$. This may be a way to use technology, organization of production, organizational and managerial solutions for this technology implementation, options for its dissemination, etc. Technologies ( $\mathrm{T}$ ) generate (K'), which in the future become the basis of new technologies ( $\left.T^{\prime}\right)$. In turn, ( $\left.T^{\prime}\right)$ generate ( $\left.K^{\prime \prime}\right)$ and so on $\left(\mathrm{K}_{\mathrm{in}} \ldots \mathrm{K}_{\mathrm{in}}^{\prime} ; \mathrm{T}_{\mathrm{in}} \ldots \mathrm{T}_{\text {in }}\right)$, which by their nature are the links of scientific and technological progress. In this process, knowledge, when it is aggregated and forms the core of a new technology, is characterized by a number of effects (convergence, synergy, spillover effect, etc.). The mutual permeability of knowledge is no longer the usual sum of the knowledge components, but has a new added value. The interaction of knowledge and technology is explicit, due to their paradigmatic ties actualization.
The object of creativeness, which was recorded in $\mathrm{T}$ 'when the action over $\mathrm{K}$ was taken, and, accordingly, $\mathrm{K}$ ' and the intellectual property were received, which is based on $\mathrm{K}$, is an independent legal category. The transfer of each of these rights is an independent legal fact that generates, changes, and terminates the legal relationship. This confirms the hypothesis about the conceptual difference between $K$ and $K$, as well as the way of their development.

The proposed approach to technology development on the basis of knowledge transformation chains enables to increase the substantiation of technology management processes within their transfer, to take into account the emergence of market-driven technologies (in particular, synergy, convergence, technology diffusion, multiplica- 
tive effect, spillover effect, crowd effect, etc.), and, accordingly, evaluate business opportunities due to these phenomena.

5. Influence of technology transfer on the university subsystems. Technology transfer from universities to the business environment has an impact on all university subsystems. In particular, the development of technologies to be transferred, the implementation and enhancement of the professionalism of scientific and technical workers in the R\&D subsystem; support for the transfer of technology developed at universities in all areas and fields, as well as technologies provided to universities for transfer; university intellectualization - in the administrative subsystem; learning through research or through the applied projects development - in the education subsystem; multifaceted support for commercialization and technology transfer (technological audit, cost estimation, intellectual property protection, marketing research, etc.) - in the subsystem of innovations; ensuring the integration of science and production - in the production subsystem. University resources allow to provide the appropriate technical, economic, marketing, legal and other types of technology support necessary for their transfer.

6. Models of interaction in the "University Governmental Authority - Business" system. The analysis of the current triple helix of the University - Power - Business interaction and the prospects for Ukraine's transition to the quadruple multiplicative co-operation spiral in the "University - Governmental Authority - Business - Consumers" system showed that universities became important, equivalent to others, participants in technology transfer and the basis of the knowledge economy. Enterprises benefit from increasing the number of technologies developed in universities and technology transferred to businesses, accelerating the country's innovative development. By creating channels for technology transfer, as well as organizing platforms for its successful implementation, universities take on entrepreneurial functions. At the universities, business incubators, science and technology parks, different innovation development organizations and others are created. As a result, universities have the ability to quickly transfer knowledge to a practical level. At the same time, universities are implementing a number of modern educational and research programs, which often serve as a stimulus for the R\&D demand. Scientists and inventors are becoming an important economic resource in the technology production and transfer. Thus, the formation of theoretical and methodological principles for the technology transfer from universities to the business environment in Ukraine nowadays has become an actual need.

7. Technology transfer effects. Expanding the traditional approach to technology transfer management, taking into account its effect, is especially important in the case of managing complex structures such as universities. Working out the specific variants of the technology transfer effects and determining the conditions under which these options can be met will allow to adjust the conditions for the technology transfer, and strengthen management flexibility. Among the important effects we select spillover effect, convergence effect, multiplicative effect, synergy effect, and crowd effect. Currently, the study of the technology transfer effects has not enough attention in both domestic and foreign literature. Let us consider the basic characteristics of these effects.

In economic terms, the spillover effect is a secondary effect that can occur in other temporal and spatial dimensions of the event that caused the primary effect. The spillover effect is a key element of the neo-functionalist theory described by Monnet (1976). In fact, the spillover effect is a situation where one phenomenon results in another, because both the first and the second are not related to each other in a common context. The spillover effect is manifested multiplicatively, due to the specific knowledge and technology interaction. It is not always possible to foresee the emergence of a spillover effect in the technology transfer, because this effect is characterized by relative suddenness. It is important to study the spillover effects under possible spread of technologies.

Besides spillover effects, during technology transfer, the convergence of technologies may occur. 
Nowadays, there is no unambiguous definition of convergence in the economic area. Tinbergen (1972) was the first to offer the phenomenon of convergence in economics. Proceeding from the principles of classically interpreted causal relationships, convergence is found in an interdisciplinary or transdisciplinary environment. Given existing attitudes towards understanding convergence, we can assume that in the broad sense, convergence within the technology transfer is the combination of technologies scope (or R\&D results) and/or methods of their dissemination, etc., for the purpose of inventing a new technology or improvement of the existing one.

Le Bon was first to describe the crowd effect in 1896 as a type of irrational behavior of subjects (Le Bon, 1977). In a university environment, the crowd effect occurs when technologies originating from universities can have advantages of the spillover effect and convergence, but at the same time, they compete in the technology market. The crowd effect is achieving the higher relevance of certain types of R\&D implementation, when compared to other types. This effect reflects an increase in the number of technology generation in a particular area, while there takes place the decline in such activities in other areas.

The multiplicative effect (multiplication effect) arises when technology is brought to market. This effect is described by the theory of multiplicative effects by Keynes (1978). First of all, it concerns technologies that are product innovations, intended for productions. The multiplicative effect consists in the accumulation of additional revenue from these technologies application in the production. In practice, the initial multiplicative effect may occur again and again, due to the multiple and multifaceted application of this technology, not only in the originally determined market, but also in other, by other business entities, in other industries, etc.

Among the effects of technology transfer, synergy holds a ranking place (from the Greek ovvepyía -

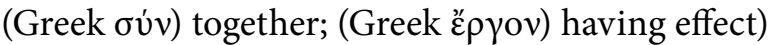
- the overall effect, the essence of which is that two or more components, when interacting, essentially prevail those effects that would have each component separately, or in their sum. Eggertsson (1990) described synergy as an element of the synergetic theory. Technology synergy arises as a result of the merger of technologies, mostly developed by various economic entities, as well as technological aspects such as knowledge and skills, infrastructure, means of production, etc. Synergy from technology transfer arises when the key advantages of business entities in the given technological field are activated.

Along with the described effects, it is necessary to consider the diffusion of technologies. For the first time, the phenomenon of innovative technologies diffusion has been described by Hägerstrand (1967) within the theory of spatial diffusion of innovations, according to which the whole process of socio-economic development results from the creation of innovation and its dissemination. The concept of innovations diffusion was systematized by Rogers (2009), and it envisages the following key aspects: innovations, communication channels, decision-making period for innovations, social system. Taking these aspects into account when transferring technologies from universities to the business environment is often an important prerequisite for predicting the technology transfer effects mentioned above. Diffusion of innovative technologies, according to Rogers (2003), includes five stages: 1) knowledge, 2) beliefs, 3) solutions, 4) implementation, and 5) confirmation, taking into account what one can predict the nature of the origin and the type of the technology effect.

From the theoretical and methodological positions, the abovementioned effects of technology transfer arise in the interaction of certain branches of knowledge within the theories they describe with the branches of the innovation theory. The theory of innovations includes knowledge areas, which taken together define a chain of actions: from development to technology transfer, namely: heuristics (responsible for the creative thinking), invention theory (responsible for the implementation of the idea), and innovation theory (responsible for the implementation of innovations). At the intersection of these knowledge areas, the technology appears. Figure 3 represents the relationship between the theory of innovation and other theories, resulting in the corresponding effects of technology transfer. 


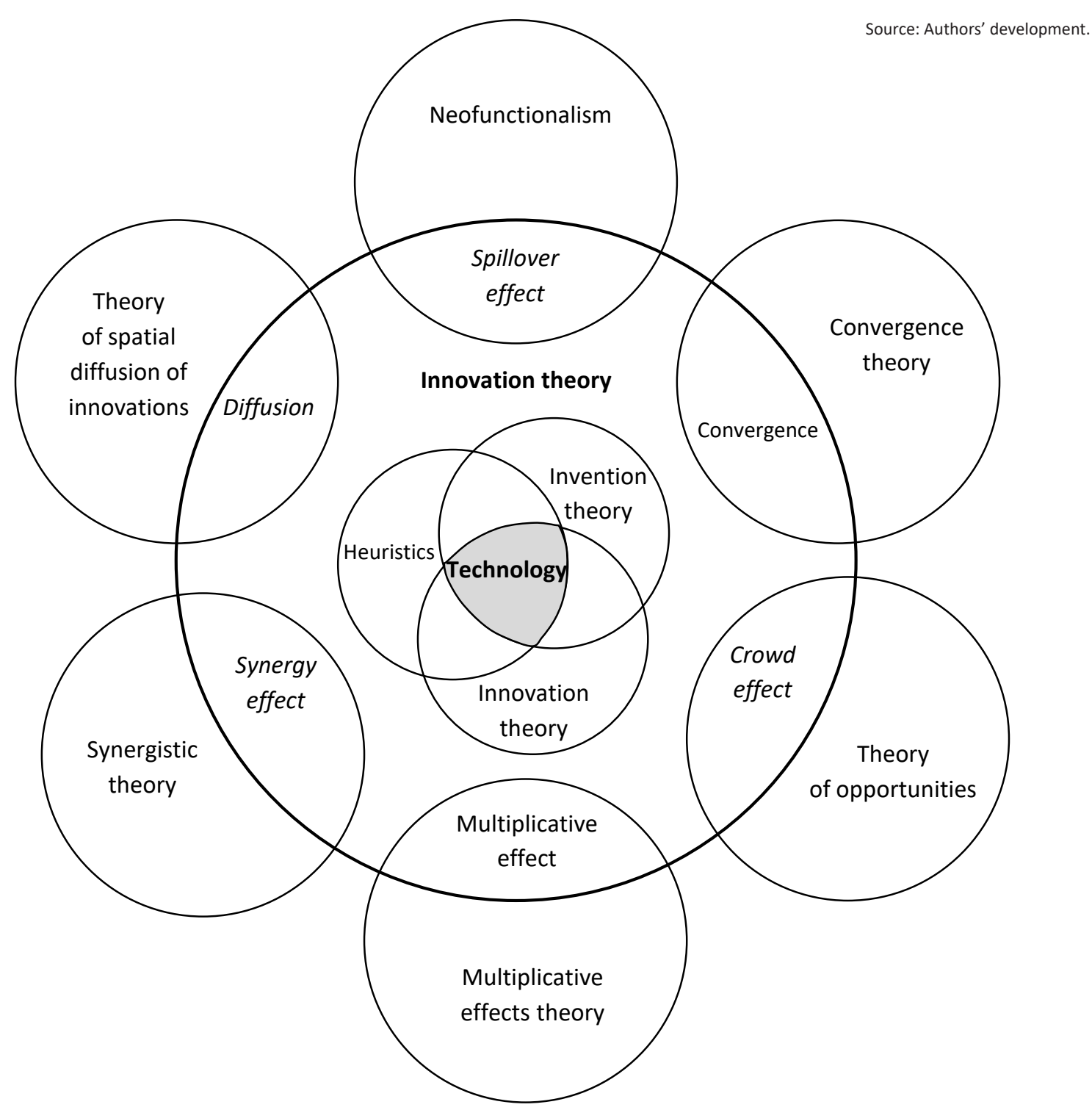

Figure 3. Mutual influence of theories within the technology transfer

In the diagram (Figure 3), the focus is on the theoretical bases connection, which is dually implemented: on the one hand, by the emergence of transfer, the technology leads to the acquisition of new knowledge within the knowledge areas of the relevant theories, on the other hand, new knowledge influences the knowledge area of the innovation theory contributing to new technologies creation.

Schematically, the occurrence and the running of the described effects during the technology transfer is presented in Figure 4.

Figure 3 shows a fragment of the typical process flow in the modern technology transfer, which begins with the development of technologies at universities, based on the knowledge resources $(\mathrm{K})$, which are transferred to enterprises in the form of goods $(T)$. In turn, new knowledge $\left(K^{\prime}\right)$ determining the technology impact on the market may result from the technologies introduction by enterprises. Knowledge ( $K$ ') under the influence of these effects leads to the development of new technologies $(\mathrm{T}$ '), which subsequently also contribute to the emergence of new knowledge $\left(K^{\prime \prime}\right)$. Accordingly, this knowledge goes to universities and becomes the basis for new R\&D and new technologies. As a result, there is the development of all actors involved in the process: the university, enterprises, and the market. 


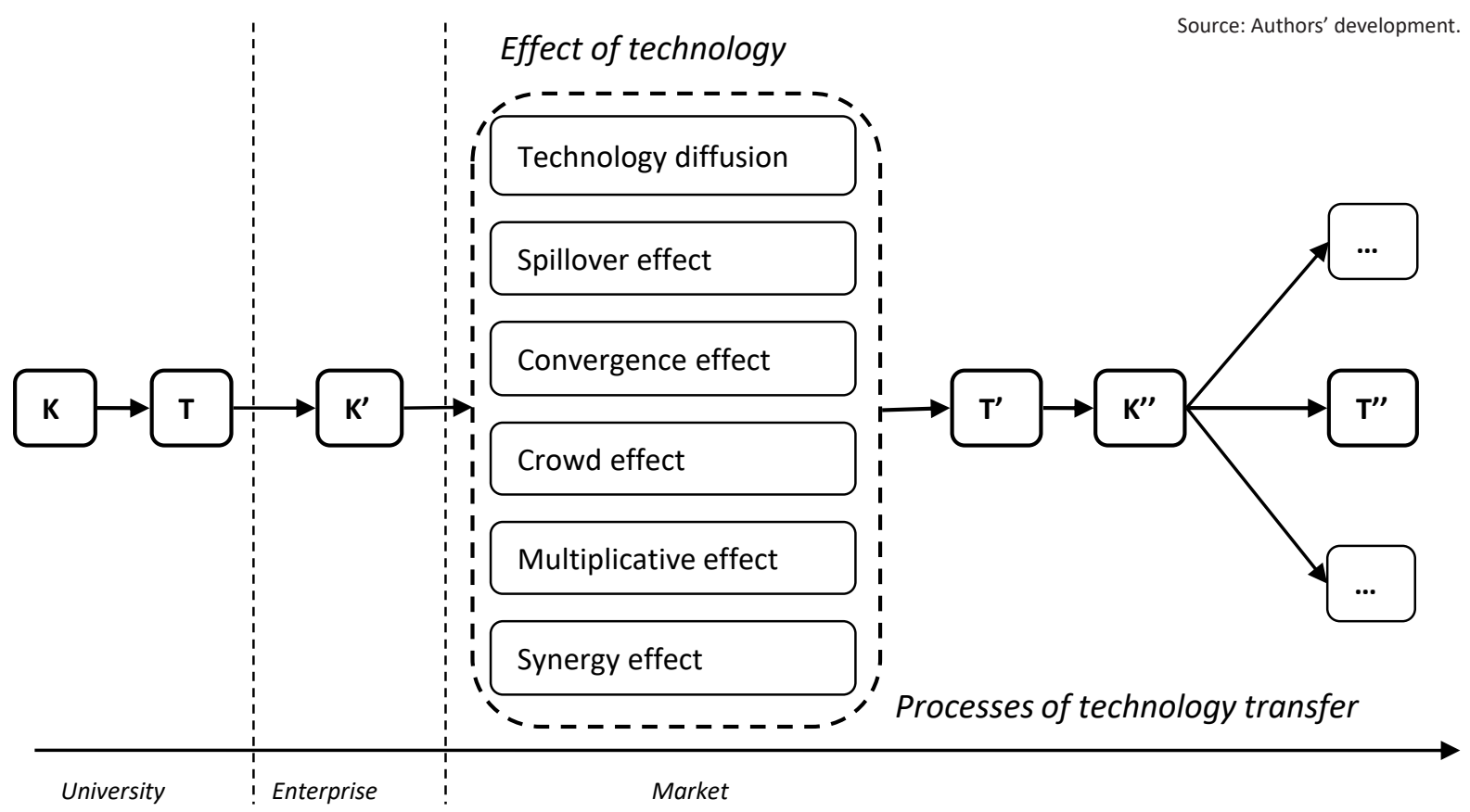

Figure 4. The emergence and effect of technology transfer

The importance of studying the technology transfer effects can be attributed to the possibility of their considering at the initial stages of technology transfer preparation, which will allow for more accurate justification of technologies' cost estimates. An entity, while developing technology and evaluating the possibility of having one or another type of effect (for example, identifying the consumer value of this technology in other industries), can add value to the price of technology in its transfer.

Taking the described effects of technology transfer into account can enable both TTC managers and other business entities involved in predicting technology transfer efficiency to manage technology transfer on a higher-precision basis, and improve management flexibility.

8. Modern approaches to technology transfer from universities to the business environment. Universities are most susceptible to any changes in global technological processes. Nowadays, there are changes in the nature of innovation: the technology push model replaces the marketing pull model. The current state policy of Ukraine is based on the model of technological push, according to which generating the innovative technologies begins with the hypothesis of a new scientific re- search, R\&D and all subsequent stages of technology passing, and results of its transfer. At the same time, this model has disadvantages. In particular, technologies originating from the university environment generally require significant investment from investors, industry, etc. There is a high risk of market rejection of university technologies.

The experience of the United States and the EU countries reveals that the engagement of universities in academic entrepreneurship is based on the marketing pull prevalence: universities generate technologies demanded by market players.

Ukrainian universities should gradually reorient themselves so that their R\&D results meet market demand. In turn, this will result in greater demand for university technologies and increase their commercialization.

In our view, the features and trends of technology transfer from universities to the business environment in Ukraine point to the urgent need to form theoretical and methodological principles of technology transfer. These principles will include all prerequisites and trends, scientific perspectives and applied developments that determine the technology transfer at the present stage of devel- 


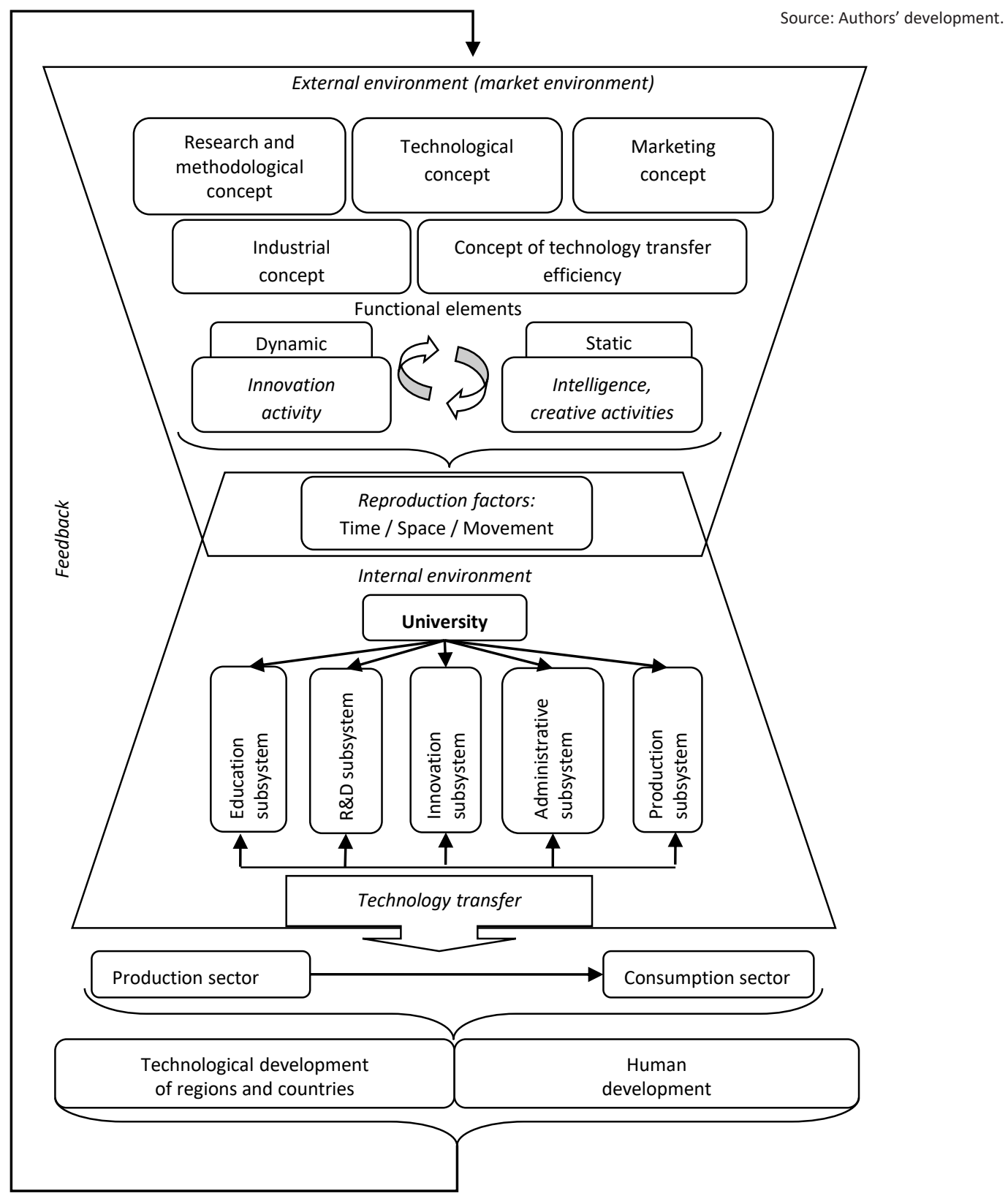

Figure 5. Conceptual approach to understanding of technology transfer from universities to business environment

opment and will serve as a benchmark for further work in this area. Theoretical and methodological principles of technology transfer from universities to the business environment are a conceptual basis for setting the problem of technology transfer and ways of its solution; they are based on a synthesis of existing approaches that have been developed during the period of technology transfer actualization.

Given the abovementioned theoretical and methodological principles, a conceptual approach to the understanding of the technology transfer from universities to the business environment was formed (Figure 5).

Technology transfer from universities to the business environment should be understood as a multidimensional interaction between the university subsystems with each other and the external environment, based on maximizing the technology transfer efficiency. The factors of the external and internal environment of the university interact based on knowledge transformation into tech- 
nology (product), which results in new knowledge, which in turn, will be used to generate new technologies.

The conceptual approach to understanding the technology transfer from universities to the business environment provides an understanding of the subject of technology transfer as a relationship between its participants in creating and transferring the added value in the form of technologies, taking into account the impact of world technological development.

The described approach shows the basis for the complete process of technology transfer from universities to the business environment: the preconditions resulting from the market environment (they can be scientific, methodological, technological, marketing, industrial and based on the technology transfer efficiency), in which dynamic and static elements are integrated, which, affected by reproduction factors, are induced to the technologies development and transfer (from universities). Technologies can be designed for both the production sector and/or the consumption sector. The effective technologies application, their spread, as well as some type of effect (convergence, spillover effect, etc.) emergence, contribute to the technological development of the university, region, country and society. On the basis of the technologies transfer, the new types of knowledge appeared, which became the prerequisites for new technology development and transfer (feedback).

The objective function of technology transfer is methodologically determined by the target priorities of technology transfer participants (effective commercialization, ensuring the competitive advantages of enterprises and universities, technological development of the country, etc.).

\section{CONCLUSION}

The research makes it possible to determine the main theoretical and applied bases of technology transfer, in particular:

- the modern technological development of the countries testifies that universities are and in the long run will remain their main participants, which is going on by intensifying the technology transfer. This gives grounds for shaping theoretical and methodological principles of technology transfer from universities to the business environment;

- it is important to make transfer technology centers more effective, in particular taking into account their own technology transfer concepts. This will allow to consider the specifics of the university and to identify the technology transfer nature. Accordingly, it is important to increase the technology transfer efficiency;

- the proposed approach to the understanding of technology development based on knowledge transfer chains enables to substantiate technology management processes, in particular, at universities; take into account market phenomena (synergy, convergence, diffusion of technologies, multiplicative effect, spillover effect, crowd effect, etc.) and, accordingly, evaluate the business opportunities determined by them. This provision is one of the main theoretical and methodological foundations of modern technology transfer;

- the need to maintain a balance between the marketing pull and technological push models. Given these models, Ukrainian universities need to gradually shift their focus to ensure that their R\&D results meet market demand and take the path towards successful academic entrepreneurship.

On the basis of the research, theoretical and methodological principles of technology transfer from universities to the business environment have been formed: they determine scientific and practical problems of technology transfer and the ways to solve them, rely on world and domestic tendencies in the 
field of technology transfer, focus on universities as the driving forces of technology transfer, formed on the basis of scientific approaches developed during the technology transfer actualization.

The theoretical and methodological principles of technology transfer from universities to the business environment will facilitate:

- developing mechanisms for encouraging cooperation between universities, authorities and business environment actors in the context of technology transfer;

- elaboration and development of mechanisms for TTC creation at universities, which will enable them to effectively evaluate technologies and introduce them to the market; will help to reduce the path of "R\&D $\rightarrow$ Production $\rightarrow$ Market (Commercialization)";

- developing a strategy for interdisciplinary communication that focuses on the role of knowledge enhancing the material content of technologies during their transfer;

- interpreting the technology transfer as a phenomenon that affects all university subsystems. This allows to justify the technology transfer that is characteristic of each particular university;

- considering different types of effects from technology introduction to the market (spillover effect, convergence effect, multiplicative effect, synergy effect and crowd effect), which will help to more accurately justify the cost estimation of technology and manage technology transfer more flexibly;

- developing the methodology for evaluating technologies in their preparation for the transfer.

Though scientific and technical areas in Ukraine have high potential, the interaction between business and universities is weak. R\&D orders in Ukrainian universities are only gaining momentum. In our view, when applying individual adaptation measures for the technology transfer development, Ukrainian universities should take into account the influence of the global institutional environment. The basic aspect of such measures should be the nation-wide policy of managing science and technology advancement in Ukraine, the development of which takes into account the long-term priorities of the intellectual potential development, promoting the commercialization of innovative technologies, etc.

\section{REFERENCES}

1. Androsova, O. F. (2006). Організаційно-економічні аспекти використання трансферу технологій на підприємствах авіаційної промисловості [Orhanizatsiinoekonomichni aspekty vykorystannia transferu tekhnolohii na pidpryiemstvakh aviatsiinoi promyslovosti]. Extended abstract of candidate's thesis. Kyiv: NAU.

2. Bercovitz, J., \& Feldman, M. (2006). Entrepreneurial Universities and Technology Transfer: A Conceptual Framework for Understanding Knowledge-Based Economic Development. The Journal of Technology Transfer, 31(1), 175-188.
3. Bickmore, D. A., \& Law, J. (Eds). (2013). Technology Transfer Desk Reference: A Comprehensive Guide to Technology Transfer (6th ed.). NJ: Federal Laboratory Consortium for Technology Transfer.

4. Bloomberg Finance L. P. Retrieved from https://www.bloomberg. com/company/

5. Butenko, D. S., \& Tkachuk, I. I. (2015). Трансфер інноваційних технологій: сутність і значення для сучасної економіки України [Transfer innovatsiinykh tekhnolohii: sutnist i znachennia dlia suchasnoi ekonomiky
Ukrainy]. Hlobalni ta natsionalni problemy ekonomiky, 3, 232-235.

6. Butnik-Siverskyi, S. F. et al. (2006). Економіко-правові проблеми в сфері інтелектуальної власності [Ekonomiko-pravovi problemy $v$ sferi intelektualnoi vlasnosti]. Kyiv: NDI intelektualnoi vlasnosti APrN Ukrainy.

7. Carayannis, E. G., \& Campbell, D. F. J. (2009). "Mode 3" and "Quadruple Helix": toward a 21st century fractal innovation ecosystem. International Journal of Technology Management, 46(3/4), 201-234.

8. Chen, J. K. C., Chiu, W.-H., Kong, S. F. L., Leo, Y. T., \& Lin (2010). 
Evaluating Global Technology Transfer Research Performance. China: IEEE.

9. Chesbrough, H. W., \& Vanhaverbeke, W. (2006). Open Innovation: Researching a New Paradigm. NY: Oxford University Press.

10. Chukhray, N. I., \& Shcherbata, T. S. (2016). Співробітництво між підприємствами-виробниками інформаційно-технологічного продуктута BH3 [Spivrobitnytstvo mizh pidpryiemstvamyvyrobnykamy informatsiinotekhnolohichnoho produktu ta VNZ]. Marketynh i menedzhment innovatsii, 3, 161-169.

11. Dovbenko, V. I. (2013). Роль потенціалу трансферу знань і технологій в інноваційному процесі [Rol potentsialu transferu znan i tekhnolohii $\mathrm{v}$ innovatsiinomu protsesi]. Menedzhment ta pidpryiemnytstvo $\checkmark$ Ukraini: etapy stanovlennia $i$ problemy rozvytku, 776, 254-263.

12. Eggertsson, T. (1990). Economic Behavior and Institutions: Principles of Neoinstitutional Economics (Cambridge Surveys of Economic Literature) (404 p.). Cambridge University Press.

13. Etzkowitz, H. (1983). Entrepreneurial Scientists and Entrepreneurial Universities in American Academic Science. Minerva, 21(2-3), 198-233.

14. Friedman, J., \& Silberman, J. (2003). University technology transfer: do incentives, management and locations matter? The Journal of Technology Transfer, 28(1), 17-30.

15. FY2015: U.S. Licensing Activity Survey (2017). NY: The Association of University Technology Managers. Retrieved from https://www.autm.net

16. Gibson, D., \& Smilor, R. (1991). Key Variables in Technology Transfer: A Field-Study Based Empirical Analysis. Journal of Engineering and Technology Management, 8, 287-312.

17. Global innovation index. Retrieved from https://www.globalinnovationindex.org
18. Grosul, V. А. (2010). Проблеми інноваційної діяльності в Україні [Problemy innovatsiinoi diialnosti v Ukraini]. Biuleten Mizhnarodnoho Nobelivskoho ekonomichnoho forumu, 1(3), 76-82.

19. Hägerstrand, T. (1967). Innovation diffusion as a spatial process. Retrieved from https://www.worldcat.org/title/innovation-diffusionas-a-spatial-process/oclc/536383

20. Heiets, V. M. et al. (2015). Інноваційна Украӥна - 2020: національна доповідь [Innovatsiina Ukraina - 2020: natsionalna dopovid]. Retrieved from http://ief.org.ua/wp-content/ uploads/2015/07/ІнноваційнаУкраїна-2020++.pdf

21. Illiashenko, S. M. (2011). Інтелектуальний капітал ВН3 як запорука його інноваційного розвитку: сутність, структура, підходи до оцінки [Intelektualnyi kapital VNZ yak zaporuka yoho innovatsiinoho rozvytku: sutnist, struktura, pidkhody do otsinky]. Marketynh i menedzhment innovatsii, 1, 145-154.

22. Izhevskyi, Р. Н. (2006). Ефективність організаційних форм трансферу технологій на виробничих підприємствах [Efektyvnist orhanizatsiinykh form transferu tekhnolohii na vyrobnychykh pidpryiemstvakh]. Extended abstract of candidate's thesis. Khmelnytskyi: KhNU.

23. Kamianska, O. V. (2008). Управління трансфером технологій на машинобудівних підприємтсвах [Upravlinnia transferom tekhnolohii na mashynobudivnykh pidpryiemstvakh]. Candidate's thesis. Kyiv: National Technical University of Ukraine "Kyiv Polytechnic Institute".

24. Karmazina, O. O. (n.d.). Наукова та інноваційна діяльність України: статистичний збірник [Naukova ta innovatsiina diialnist Ukrainy: statystychnyi zbirnyk]. Retrieved from https://ukrstat. org/uk/druk/publicat/kat_u/ publnauka_u.htm

25. Keyns, J. M. (1965). The General Theory of Employment, Interest and Money (1st ed.). Harcourt, Brace $\&$ World.
26. Kislenko, O. V. (Ed.) (2016). Здійснення наукових досліджень і розробок в Україні. Доповідь [Zdiisnennia naukovykh doslidzhen i rozrobok $v$ Ukraini. Dopovid]. Kyiv: Derzhavna sluzhba statystyky Ukrainy.

27. Kniaz, S. V., \& Heorhiadi, N. H. (2011). Трансферний потенціал інноваційного розвитку підприємства: сутність і характеристики [Transfernyi potentsial innovatsiinoho rozvytku pidpryiemstva: sutnist i kharakterystyky]. Menedzhment ta pidpryiemnytstvo $v$ Ukraini: etapy stanovlennia ta problemy rozvytku, 714, 341-348.

28. Kosenko, O. Р. (2016). Організаційно-економічний механізм комерціалізації інтелектуально-інноваційних технологій на машинобудівному підприємстві [Orhanizatsiinoekonomichnyi mekhanizm komertsializatsii intelektualnoinnovatsiinykh tekhnolohii na mashynobudivnomu pidpryiemstvi]. Doctor's thesis. Kharkiv: National Technical University of Ukraine "Kharkiv Polytechnic Institute".

29. Le Bon, G. (1977). The Crowd. New York: Penguin Books.

30. Liashenko, О. М. (2009). Методи та моделі комерціалізації трансферу технологій [Metody ta modeli komertsializatsii transferu tekhnolohii]. Doctor's thesis. Kyiv: Institute for Economics and Forecasting of NAS of Ukraine.

31. Mansfield, E. (1975). East-West technological transfer issues and problems, international technology transfer: Forms, resource requirements, and policies. American Economic Review, 65(2), 372-376.

32. Mayer, S., \& Blaas, W. (2002). Technology transfer: an opportunity for small open economies. The Journal of Technology Transfer, 27(3), 275-289.

33. Monnet, J. (1976). Memoires. Paris: Artheme Fayard.

34. Mrykhina, O. B. (2017). Conceptual framework for the formation of information and analytical 
system for technology transfer. Aktualni Problemy Ekonomiky, 158, 454-463.

35. Pererva, P. H., \& Hladenko I. V. (2010). Моніторинг інноваційної діяльності: інтерпретація результатів [Monitorynh innovatsiinoi diialnosti: interpretatsiia rezultativ]. Marketynh i menedzhment innovatsii, 2, 108-116.

36. Rogers, E. (2003). Diffusion of Innovations (5th ed.). Simon and Schuster.

37. Salikhova, O. В. (2003). Удосконалення методології статистичного аналізу міжнародного трансферу технологій в Україні [Udoskonalennia metodolohii statystychnoho analizu mizhnarodnoho transferu tekhnolohii v Ukraini]. Extended abstract of candidate's thesis. Kyiv: Institute for Scientific and Technological Potential and Science History Studies. AHEM. Dobrov NAS UKRAINE.

38. Schwab, K. (Ed.). (2017). The Global Competitiveness Report 2016-2017. Geneva: World
Economic Forum. Retrieved from http://www3.weforum.org/docs/ GCR2016-2017/05FullReport/ TheGlobalCompetitivenessReport2016-2017_FINAL.pdf

39. Tinbergen, J. (1972). De convergentietheorie: antikritiek (The Convergence Theory: Anti-Criticism). Retrieved from https://books.google.com.ua/ books?hl=uk\&lr=\&id=xupgf_cI y2YC\&oi=fnd\&pg=PA41\&dq $=\mathrm{T}$ inbergen,+J.+(1972-3),+'De+co nvergentietheorie:+antikritiek'+ (The+Convergence+Theory:+An ti-Criticism)

40. Tsybuliov, P. M., Chebotarov, V. P., Zinov, V. H., \& Suini, Iu. (2005). Управління інтелектуальною власністю [Upravlinnia intelektualnoiu vlasnistiu]. Kyiv: "K.I.S.".

41. World Intellectual Property Organization. Retrieved from http://www.wipo.int/about-ip/en/

42. Yastremska, O. M., \& Vereshchahina, H. V. (2010). Управління інноваційною діяльністю [Upravlinnia innovatsiinoiu diialnistiu]. Kharkiv: INZHEK.
43. Державна служба статистики України [Derzhavna sluzhba statystyky Ukrainy]. Retrieved from https://ukrstat.org/zb_nayka_2016

44. Державна служба статистики України [Derzhavna sluzhba statystyky Ukrainy]. Retrieved from https://ukrstat.org/dop_ inn_2016

45. Закон України Про наукову науково-технічну діяльність [Zakon Ukrainy Pro naukovu i naukovo-tekhnichnu diialnist] (n.d.). Retrieved from http://zakon2. rada.gov.ua/laws/show/848-19.

46. Наукова та інноваційна діяльність України (2017): статистичний збірник [Naukova ta innovatsiina diialnist Ukrainy: statystychnyi zbirnyk]. Retrieved from https://ukrstat.org/uk/druk/ publicat/kat_u/publnauka_u.htm

47. Розпорядження Кабінету міністрів України Про схвалення концепції розвитку національної інноваційної системи [Rozporiadzhennia Kabinetu ministriv Ukrainy Pro skhvalennia Kontseptsii rozvytku natsionalnoi innovatsiinoi systemy (n.d.). Retrieved from http://zakon2.rada. gov.ua/laws/show/680-2009-p 